\title{
La participación de las élites madrileñas en la industria cinematográfica
}

\author{
Josefina Martínez Álvarez *
}

\section{INTRODUCCIÓN}

En sus orígenes, el cinematógrafo fue concebido más como un avance científico que como una curiosidad o "divertimento". Todas las investigaciones que se llevaron a cabo durante el siglo XIX y que concluyeron con el nacimiento de la fotografía animada, se habían hecho en nombre de la ciencia.

Por ello, cuando Promio, delegado de los hermanos Lumière en Madrid, presenta el 15 de mayo de 1896 el cinematógrafo en España, no lo hace en una barraca de feria, sino en un local situado en el centro aristocrático y burgués de la ciudad, en la Carrera de San Jerónimo. Que el invento iba dirigido a este sector de la población, lo demuestra también el elevado precio de las entradas, que venía a ser el doble del importe de una localidad de cualquier teatro o salón de la capital y, por ello, asequible únicamente para las élites a que iba dirigido. $Y$ estas élites serán las primeras en comparecer en la presentación de uno de los mayores inventos del siglo ${ }^{1}$.

* UNED.

'El año anterior, los madrileños habían podido contemplar en el mismo local el Kinetoscopio de T. Alva Edison, aparato de imágenes en movimiento pero de visión individual. Un mes antes de la presentación del cinematógrafo, en el circo de Parish se había presentado el Animatógrafo, proyector similar al de los Lumière pero de patente inglesa, inventado por Robert W. Paul. Debido a la preponderancia de la industria cinematográfica francesa, el Animatógrafo quedará postergado, al igual que otros aparatos similares. 
Aunque la trayectoria de la exhibición del cinematógrafo variará a través de los años, hasta pasar a formar parte de los espectáculos populares, sin dejar por ello de ser elitista, los que participan en el sector de la producción cinematógrafica en Madrid, cuando ésta comienza a despuntar, serán la burguesía y la aristocracia. Son ellas las que poseen el poder económico necesario para invertir y crear la nueva industria.

\section{LA MONARQUIÁ Y EL CINEMATÓGRAFO}

El poder de atracción que ejercía el cinematógrafo sedujo pronto a la monarquía española, tanto a la Reina Regente como al futuro Alfonso XIII, quien durante su mandato llega a participar directamente en la industria cinematográfica madrileña.

Uno de los primeros pasos que dio Promio a su llegado a Madrid, fue ser recibido por la reina María Cristina, que le concedió los permisos necesarios para captar con su cámara escenas de distintos cuerpos del ejército y de la guardia de Palacio. Toda la familia real asiste, el 4 de junio de 1896, al salón de la Carrera de San Jerónimo para contemplar estas imágenes y otras películas de la casa francesa. Años después se instalaría un cinematógrafo en el propio Palacio Real.

Alfonso XIII pronto demostró, al igual que otros monarcas europeos, su deferencia hacia el cine. Recibió en 1901 su primera cámara de bolsillo y al año siguiente, con motivo de su coronación, aparece ya en las pantallas. A partir de este momento y hasta su salida de España, el Rey se convierte en uno de los personajes principales de los documentales. Estas películas constituyen una fuente historiográfica de primer orden, ya que permiten contemplar la evolución social y política de España durante el reinado de Alfonso XIII.

Desde la caravana de coches al Pardo para homenajear a la futura Reina Ena Victoria, sus bodas reales, los viajes oficiales a Alicante, Valencia, Cartagena, Lérida, Zaragoza, Barcelona, Sevilla, Italia, Francia, África, etc., hasta sus cacerías, los juegos de polo o la asistencia a espectáculos deportivos, todos ellos han quedado impresos en el celuloide ${ }^{2}$.

${ }^{2}$ Estas películas formaban parte de la filmoteca de Palacio y posteriormente pasaron a engrosar los fondos del archivo de RTVE y de Filmoteca Española. 
Además de ser «actor», Alfonso XIII fue un notable espectador. En el cine de Palacio, todos los meses se proyectaban las películas más interesantes del momento. El Rey acudia también a los principales teatros de Madrid (la Zarzuela, el Gran Teatro, el Price), ya fuera a las galas aristocráticas para conocer los programas inaugurales de temporada, ya fuera a las sesiones especiales.

Un último y significativo aspecto en la relación que Alfonso XIII mantuvo con el cinematógrafo, fue su participación en la primera gran productora madrileña, la Atlántida, en la que invirtió parte de su capital para la compra de acciones de la sociedad.

En los primeros tiempos de la Atlántida, Alfonso XIII estuvo muy ligado a la productora, que mantuvo una continua correspondencia con el monarca para informarle de los sucesos acaecidos en la empresa. El Rey facilitó los rodajes de algunas de sus películas, al conceder los permisos necesarios para que se filmasen escenas en lugares del patrimonio real, como Aranjuez o La Granja de San Ildefonso.

Gracias a esta relación se ha podido conocer la trayectoria de la Atlántida desde su nacimiento en 1919 hasta su disolución en 1926, al encontrarse en el Archivo General de Palacio la única documentación que sobre esta productora se ha conservado.

\section{“AHORA LOS PRINCIPES VAN A SER PELICULEROS"}

Con esta irónica frase, escrita por un crítico cinematógrafico, Ruiz Margarit, de la revista catalana Arte y Cinematografía, queda resumida una situación que iba a ponerse en boga en Madrid a partir de 1913: la introducción de la aristocracia en la producción cinematográfica.

En Barcelona, desde 1896 se rabía ido consolidando la industria del cine. Allí se establecieron varias casas productoras, con sus estudios de rodaje y laboratorios, así como las principales revistas cinematográficas, El Cine y Arte y Cinematografía. Puede decirse que, salvo algunas pequeñas firmas en Galicia, el País Vasco o Madrid, no existía producción cinematográfica fuera de Cataluña. Hasta 1923 Madrid no empezará a tomar la alternativa en este terreno.

Pero ya a partir de 1910 se sientan en Madrid las bases de esta industria. Primero - y casi hasta 1920 - con una estructura atomizada, dentro de la que surgen pequeñas productoras, casas artesanales y fa- 
miliares donde se filman documentales o películas de ficción cuya exhibición no sobrepasa el ámbito local.

Pero comenzará a darse en la capital de España un fenómeno distinto al que vive Cataluña. La industria madrileña está patrocinada por los aristócratas, en lugar de por profesionales que se van formando en este campo. El primer ejemplo de ello será el conde de Vilana.

Al comprobarse en Madrid, hacia 1913, el éxito de las películas cómicas extranjeras, sobre todo las francesas de "Toribio" (André Dee), el conde de Vilana, a propuesta de un grupo de actores teatrales, decide financiar varias cintas de 300 y 400 metros protagonizadas por Joaquín Martínez Palomo. Estas películas se hacian con guiones improvisados, y su gracia se limitaba a los golpes recibidos por el protagonista.

Además del capital, el conde de Vilana puso su palacete para rodar los interiores. De este modo nacería «Las aventuras del pollo Palomeque», que se estrenó en el cine Principe Alfonso con una gran acogida ${ }^{3}$, lo que llevó al conde de Vilana a financiar una segunda cinta, "Los sueños de Palomeque». Interpretada por los mismos actores pero fotografiada por José Gaspar, su éxito motivó el rodaje de una tercera película, que se desarrollaba en La Bombilla ${ }^{4}$.

El éxito de los filmes del conde de Vilana animó al marqués de Camarins a producir otra película, también fotografiada por José Gaspar. Se trataba de una muestra del género policiaco, rodada en palacios y quintas, en la que intervinieron «aristócratas conocidos y sportmen de Madrid" 5 . Al estreno de "Nick Marten contra Jim», en el Principe Alfonso, el 20 de junio de 1915, acudió el «todo Madrid» bajo el pretexto de que la recaudación se dedicaría a obras benéficas.

A la industria catalana le disgustó esta intromisión de la aristocracia madrileña en la que consideraban una parcela de su propiedad. Ignoraban que por manos de esta élite iba a pasar la producción madrileña más destacada de los primeros años veinte.

${ }^{3}$ La fotografía corrió a cargo de Francisco Olivares y fue interpretada, además de por Martínez Palomo, por Elena y Antonio Riquelme y Emilio Mesejo.

${ }^{4}$ Además de los actores que habían intervenido en las anteriores, tomaron parte en ésta Ontiveros y Ramón Peña.

${ }^{5}$ El Cine, núm. 164, 6-111-15, pág. 5. En la película actuaban Anita Manso de Zúñiga, Remedios Santos Silva, Carmen Soriano, Juanito Camarins, Javier López de Carrizosa, Sixto Pérez Calvo, Joaquín Cuesta, Manolo Linares Rivas, José Cero, Pascual Vicuña, Antonio Catalán, marqués de San Dionis, Matias Figueras, Enrique Valenzuela, Ramón Narváez, Carlos Peñafiel, Enrique Rodríguez Montaner, Pedro Igual, Oliva de Gaytán, Luis Gamboa, Antonio Milla, Ignacio Pérez Ortega, Emilio Núñez y Luis Comas. 


\section{EN MANOS DE BURGUESES Y ARISTÓCRATAS}

La burguesía y la aristocracia madrileña, que con la guerra mundial habían visto aumentar sus capitales, estaban dispuestas a invertir en todo aquello que les proporcionara rápidos y grandes beneficios. Al ver las inmensas posibilidades que ofrecía la industria cinematográfica, no dudaron en lanzarse a la nueva aventura.

La plasmación de esta idea se verá en el nacimiento de la Atlántida Cinematográfica, heredera de la Cantabria Cines, productora santanderina creada para llevar a la pantalla la obra de Jacinto Benavente, Los intereses creados. Pese a que esta película resultó un desastre económico, su gerente - Manuel Herrera Oria - decidió ampliar el capital de la empresa. Convenció a varios amigos para que invirtieran en ella, e incluso llega a propornérselo al mismísimo Alfonso XIII. El Rey ya había mantenido relaciones con la Cantabria, al permitir que se utilizase el $\mathrm{Pa}$ lacio de Aranjuez para la filmación de "Los intereses creados", además de poner a los húsares de la reina a disposición de la Cantabria.

El 22 de marzo de 1919 se le hace la proposición en firme al Rey, quien contestará sin tardanza para contribuir «en nombre de sus augustos hijos con una cantidad entre 25.000 y 30.000 pesetas" $^{6}$. Aunque fuese una inversión testimonial, pues se trataba de una cantidad mínima en comparación con el volumen de inversiones en otros valores de cartera de Alfonso XIII, era suficiente como para apoyar la constitución de la nueva productora y animar a otros posibles capitalistas.

A la llamada de Herrera Oria también acudieron los marqueses de Albaida, Aledo, Sotomayor, Amazares, Hinojares, González de Castejón, el conde del Vado, el de Romanones, el vizconde de Eza... , y una larga nómina de profesionales liberales, intelectuales y burgueses de la capital. Ahora sí que los productores catalanes podían echarse las manos a la cabeza, al ver tal despliegue de títulos entre los cuadros de la administración y gerencia de la Atlántida.

${ }^{6}$ Archivo General de Palacio. Caja 2404/18. Carta del conde Aybar dirigida a Manuel Herrera Oria. 27 de marzo de 1919. 
El 21 de mayo de 1919 quedó constituida la Atlántida Cinematográfica, con un capital nominal de 4.000 .000 de pesetas ${ }^{7}$. Se confeccionaron unos ampulosos estatutos que reflejaban la administración y fines de la empresa, creada como sociedad por acciones, 8.000 en total, divididas en series, con una primera de 1.700 acciones por un valor de 500 pesetas cada una.

Esta primera serie equivalía a 865.000 pesetas, cantidad que representaba la subscripción de los otorgantes de la escritura de constitución. Las 600 acciones iniciales fueron suscritas por Alfonso XIII ${ }^{8}$.

La Atlántida se puso rápidamente en funcionamiento: se contrató a José Buchs como director artístico para concluir las películas a medio terminar de la Patria Films, y comenzar a continuación las nuevas cintas de la productora, "Expiación», "Cuidado con los ladrones", "La venganza del marino" y "La inaccesible». El coste de todas ellas no excedió las 50.000 pesetas.

En la Memoria del ejercicio de 1920, la Atlántida se daba por satisfecha con su labor, pese a arrojar un déficit de 32.891 pesetas, que pensaba enjugar con los beneficios del año siguiente. Se rodarían entonces "La señorita inútil», "Víctima del odio" y «La Verbena de la Paloma», película, ésta última, que aún se conserva y que supuso un gran derroche para la menguada economía de la Atlántida, al levantarse decorados corpóreos por primera vez en una producción madrileña. Los exteriores se rodaron, con permiso de Alfonso XIII, en los jardines de Aranjuez y, para abaratar gastos, se incluyeron fragmentos documentales de las fiestas madrileñas de aquel verano ${ }^{9}$.

La película costó más de 42.000 pesetas, pero fue tan grande su éxito que la empresa se dispuso a llevar a la pantalla todas aquellas

7 En 1914 se habían constituido en Barcelona la Segre films y la Barcinógrafo, con unos capitales nominales de 500.000 y 250.000 pesetas respectivamente. Junto con la Studio, fundada en 1915, serán las mayores productoras del momento. Mientras, en Madrid se había creado la Patria Films, con un capital de 5.000 pesetas y muchas ilusiones. Sus promotores fueron los hermanos Perojo, hijos del diputado José Perojo, dueño y director de las revistas Nuevo Mundo y El Teatro, entre ofras. El exiguo capital se vio aumentado por la aportación del Julio Roesset, y la productora se mantuvo en funcionamiento hasta que en 1919 fuera absorbida por la Atlántida, que contaría con sus propiedades (los estudios establecidos en la calle Comandante Fortea y un local de oficinas) y las de la Cantabria, que se valoraban, como capital inmobiliario, en 2.000 .000 de pesetas.

${ }^{8}$ Según se estipulaba en los estatutos, no se desembolsaría este capital, sino únicamente el $10 \%$ del valor suscrito.

"El maestro Bretón compuso una adaptación de "La Verbena de la Paloma» para su estreno cinematográfico, que se celebró en el Circo Price el 13 de diciembre de 1921. 
zarzuelas que estaban en boga. Sin embargo, a pesar de los beneficios generados por varias de sus producciones, la Atlántida mantenía unos déficits cada vez mayores, hasta el punto de tener que amortizar el capital para mantener el valor efectivo de los activos. Los grandes beneficios que esperaban los accionistas nunca llegaron y en enero de 1922 se reformaron los estatutos para liberar las acciones sin reembolso, to que redujo el capital social de 4.000 .000 a 2.000 .000 de pesetas y se pusieron en circulación 1.300 nuevas acciones a la par.

En realidad, la Atlántida se resentía de su falta de capitalización y del deseo de sus accionistas de una pronta y fácil ganancia, sin poner las miras en el futuro. Al no arriesgarse el capital, la Atlántida no podía situarse a la altura de las grandes productoras internacionales: sus películas debían competir con títulos como «El chico», de Chaplin, o «El gabinete del Doctor Caligari», «El Golem» o “Los Cuatro Jinetes», peliculas todas ellas que el paso del tiempo ha ratificado como obras de arte.

Esta carencia de inversiones será la causante de la descomposición de la Atlántida y de un proceso que comenzará a darse en Madrid: la producción a cargo de los propios directores de las películas.

José Buchs abandonará la empresa y los primitivos accionistas perderán el dominio financiero y la privilegiada relación con Alfonso XIII, que prácticamente terminará al ser adquirida la mayoría de las acciones de la Atlántida por los banqueros catalanes Bauer, quienes -en 1926- consolidarán la deuda mediante un préstamo hipotecario de 250.787 pesetas. La Atlántida pasará por un período de irregularidades administrativas tanto en la compra de acciones antiguas como en la venta de películas, que practica sólo para obtener algún beneficio inmediato. Así, la andadura de la Atlántida, creada como un «divertimento» inversionista de unos cuantos aristócratas madrileños, terminará en los Juzgados, al ser acusado de estafa su administrador, que se había fugado con el coche de la productora, la mecanógrafa y una máquina de escribir...

A causa de las cortas miras de sus creadores e inversionistas, la Atlántida nunca pudo estar a la altura de la producción cinematográfica internacional, ya que únicamente se esperaba una recuperación fácil del dinero invertido, sin crear esa auténtica infraestructura que la industria necesitaba para el desarrollo del cine español. 